\title{
CONTEMPORARY LIMITATIONS AND CHANCES FOR THE DEVELOPMENT OF SMALL AND MEDIUM ENTERPRISES AND ENTREPRENEURSHIP IN SERBIA
}

\author{
DOI: 10.17261/Pressacademia.2021.1464 \\ RJBM- V.8-ISS.4-2021(1)-p.222-232
}

\section{Ljiljana Stosic Mihajlovic ${ }^{1}$, Svetlana Trajkovic ${ }^{2}$}

${ }^{1}$ Academy of Technical and Educational Vocational Studies in Nis, Department of Economics and Management, Vranje, Serbia.

Ijiljana.stosic.mihajlovic@kademijanis.edu.rs, ORCID: 0000-0003-1660-9585

${ }^{2}$ Academy of Technical and Educational Vocational Studies in Nis, Department of Economics and Management, Vranje, Serbia. svetlana.trajkovic@akademijanis.edu.rs, ORCID: 0000-0002-2353-0747

\begin{tabular}{lll}
\hline Date Received: September 8, 2021 & Date Accepted: November 22, 2021 & open OAaccess \\
\hline
\end{tabular}

To cite this document

Mahyoub, M., Mohd Said, R. (2021). Contemporary limitations and chances for the development of small and medium enterprises and entrepreneurship in Serbia. Research Journal of Business and Management (RJBM), 8(4), 222-232.

Permanent link to this document: http://doi.org/10.17261/Pressacademia.2021.1464

Copyright: Published by PressAcademia and limited licensed re-use rights only.

\section{ABSTRACT}

Purpose- This study deals with the research of modern limitations and possibilities of development of small and medium enterprises and entrepreneurship in the Republic of Serbia. In addition, the aim of this paper is to specifically identify the problems faced by small and medium enterprises and entrepreneurship in Serbia, especially in the crisis caused by the COVID-19 pandemic, but also to identify opportunities for further development of small and medium enterprises and entrepreneurship. Their economic development contributes to the successful recovery and development of the Serbian economy, given that small and medium enterprises form the basis of the economic structure and dominate the Serbian economy.

Methodology- The paper is based on qualitative and quantitative analysis. An analysis of the relevant literature related to entrepreneurship, modern opportunities and risks in undertaking entrepreneurial ventures is given. Qualitative and quantitative research is based on the official literature and statistics and had the function to show the place and importance of entrepreneurship in relation to the modern business environment. Based on the analysis, recommendations and conclusions on the progress of entrepreneurship in the Republic of Serbia are given. This is especially important because, based on this study, the authors support the basic thesis that entrepreneurial orientation improves the competitiveness of the Serbian economy.

Findings- This research shows that by creating a business environment that encourages business and development of small and medium enterprises and entrepreneurship in Serbia, as a country in transition, and at the same time facing the global crisis caused by the COVID-19 pandemic, the competitiveness of Serbian production and economy is on track recovery and development.

Conclusion- According to the findings of this study, the impact of the modern business environment on business success in the sector of small and medium enterprises and entrepreneurship in Serbia is significant. The authors point out the situation, risks and uncertainties that the SME sector in Serbia faces before and during the pandemic. After considering the objective limitations, the chances that exist in times of uncertainty are presented. Although opportunities appear in many forms, dominant trends are always significant in shaping economic realities, such as government policy to facilitate business with significant subsidies in volatile and crisis times caused by a pandemic. This is precisely the reason for presenting certain directions and economic trends that will inevitably change the social and business environment, and the ability to adapt will determine the success of future entrepreneurs.

Keywords: Small and medium enterprises, entrepreneurship, organization, development, Serbia.

JEL Codes: D24, M21, 012

\section{INTRODUCTION}

Numerous factors condition the business excellence of small and medium enterprises (SME) in Serbia: government policy, regulatory framework, institutions, finance, culture, education, human capital, local and global markets. Harmonizing these elements can create a healthy and stimulating environment for the further development of entrepreneurial ventures. Efforts have 
been made to improve the business environment in the Republic of Serbia. However, entrepreneurship in Serbia faces a number of limitations. Some restrictions are characteristic only for some groups of entrepreneurship, while others are of a general nature.

Since 2016, Serbia has advanced by 6 positions on the Doing Business list and now occupies 44th place thanks to the simplification of the process of obtaining construction permits, the establishment of companies and the improvement of compliance with obligations. According to the Doing Business report (2020, pp.5), Serbia is late in adjusting its financial sector. Problems that still exist in the areas of recognition and transparency of the credit security system. However, despite obvious efforts to improve the business environment, Serbia has performed worse in terms of opening and employment than some other countries in transition. Namely, until 2016, the development of entrepreneurship in Serbia was really slow.

The authors (Anicic et al., 2017) point out that having in mind the following: the level of external debt, the structure of GDP (where almost $2 / 3$ is realized through non-tradable sectors), high foreign trade deficit and negative environmental results in 2016, it is easy to understand that economic policy makers in Serbia have the difficult task of preventing negative economic trends, as well as developing entrepreneurship and reducing unemployment. In these conditions, the question arises of changing economic policy that will lead to sustainable economic growth and development, eliminate regional disparities, provide the necessary level of investment and a favorable environment for the development of the SME sector. The affirmation of entrepreneurship as a whole, primarily productive entrepreneurship, can be a good start to the progressive and undoubtedly pragmatic transformation and transition of our society towards an economically developed world. Entrepreneurship strongly encourages the opening of new development opportunities. (Karavidic, 2008, pp. 2-3) SMEs are increasingly important for the development of world economies and for contributing to balanced local and regional development. (Stanisic, 2013, p. 71).

The world of private entrepreneurship offers an infinite number of possibilities. If you have a business idea and decide to take that bold step, make a business plan and take advantage of it, you will open the door to a comfortable life with the earnings and working hours you have always wanted. The most important social impact of entrepreneurship is new and innovative products and progressive impact on the community. (Ivkovic, Kvrgic, 2013, p. 56).

In the continuation of this paper, we will talk about the most important factors that determine the current position of small and medium enterprises in the economic structure of Serbia. Specifically, these are the transition and the COVID-19 pandemic. Then we will list the main indicators of the economic position of small and medium enterprises in Serbia and especially in relation to the EU. In conclusion, we listed the main problems faced by small and medium enterprises and entrepreneurship in Serbia, as well as opportunities for further development.

\section{LITERATURE REVIEW}

\subsection{The Main Factors of the Business Environment in Serbia}

Talking about the business environment, Jovanovic says that few factors can slow down managers' reactions and limit their ability to anticipate change business environment. These factors include (Jovanovic, 2015):

1. Cognitive limitations and problems associated with observation and interpretation, and responding to changing environments,

2. Managers tend to emphasize learning at a low level over a high level learning,

3. A tendency to nurture organizational employment and promotion practices homogeneity in manager's opinion, and

4. The power of institutionalized industrial practices to focus managerial attention to the status of quo.

Two authors (Petrovic\& Lekovic, 2019) in the paper analyzed the business conditions in the Southeast Europe region countries and came to the following conclusion: Entrepreneurship represents the basis of the economic activities of developed countries. It has an influence on economic development and an increase in employment rates by generating new jobs. Creating new jobs is the entrepreneurial aspiration for achieving the growth of an entrepreneurial venture. The impact of personal characteristics of entrepreneurs on the development of entrepreneurial venture aspirations in the form of high growth is evident. However, not only the influence of psychological characteristics but also the influence of demographic characteristics, the characteristics of the entrepreneurial enterprise and the business environment within which it exists, is evident. Why do some entrepreneurs show a greater tendency towards the aspirations for the growth of an entrepreneurial enterprise, which factors influence the development of this type of entrepreneur's aspiration? These research questions represent the unlimited potential for future research ventures, at least as far as entrepreneurial aspirations are concerned, a more concrete growth of entrepreneurial endeavors. 


\subsection{Transition in Serbia - Impact on the Position of Entrepreneurship}

Serbia belongs to the group of post-socialist countries. The transition in Serbia began in 2000, when the conditions for its implementation were met and it can be said that it is still ongoing. Transition is in fact a process of creating institutional preconditions for the development of private entrepreneurship. It takes lots of knowledge, creativity and pragmatism to create an environment that encourages free enterprise and enables a successful transition. (Stojanovic, 2002).

The liberalization of trade relations has created an environment for the integration of the Serbian economic system into international commodity and financial flows. The started flows of changes in the sphere of economy are influenced by numerous factors. The beginning of the transition process was accompanied by a series of negative effects, such as a drop in production and a drop in employment, with a simultaneous rise in prices. This phenomenon is called transitional stagflation. At the beginning of the transition, the privatization of state-owned enterprises emerged as a fundamental issue (Cvijanovic, Mihailovic, Simonovic, 2009). It was expected that privatization would be the driver of changes in economic flows for the better, ie that it would lead to rapid progress in the company's business. In the current economic situation in Serbia, a revision of privatized companies has been announced, and there is also no general consensus on the basic policies of the economy and society, which complicates the arduous reform process.

However, the main advantage of the actions taken in the transition is the creation of conditions for entrepreneurial initiative, so that today small and medium enterprises form the backbone of the economic system of Serbia. The degree of development of the national economy, among other things, is determined by the degree of development of entrepreneurship. (Djogic, 2016). The main goal of the transition is a fundamental change in the basic systems of organization of the economy, state and society, and the key premise of such changes is a change in the value system.

Therefore, it is necessary to finally enable the transition from a proven inefficient to an efficient economic system that will ensure the creation of greater added value and a large number of new jobs, which should result in a better quality of life for citizens in Serbia. Economic policy makers have the extremely difficult task of convincing citizens that they have achieved exceptional results on the path of transition and that the situation is better than it was. Entrepreneurship means the ability of individuals and / or groups to recognize a profitable business idea in the market, to have the knowledge and skills to realize the idea and achieve better effects, equipment, technologies and the ability to constantly innovate products / services. according to market demands (Denda, 2007).

\subsection{Small and Medium Enterprises in Serbia - Before and During the COVID-19 Pandemic}

In a market economy, cyclical ups and downs of economic activity are characteristic. In the literature related to the problems of factors influencing the dynamics of economic flows. Special attention is paid to recessions and ways to overcome them. Throughout economic history, the most important factors that have led to a slowdown in economic progress or recession, especially factors such as war, natural disasters, pandemics that have affected humanity. Regardless of their well-known effects, especially the factor related to deadly diseases was neglected, because it was considered that thanks to technical and technological progress, especially in the development of medicine, humanity is able to cope with these phenomena (Zarnowitz, 1992). In modern macroeconomics, special attention is paid to the factors that affect cyclical economic fluctuations, which are real or monetary, which act on the side of either aggregate supply or aggregate demand (Sherman \& Kolk, 1996). Also, special attention is paid to political factors because they can also generate cyclical economic (Jaksic\&Prascevic, 2019). In the Recent Economic History (2007-2013), the global recession began as a financial crisis in 2007, and soon turned into a deep recession, since the Great Depression of the 1930s. In that sense, the efforts of economists were aimed at determining the reasons for the crisis, the mistakes of the economic policy of the state that caused or contributed to it. From the point of view of finding a way to overcome the crisis, the efforts of economists were focused on measures of economic policy of states, with the aim of preventing future similar (Prascevic, 2017).

The COVID-19 pandemic in early 2020 did not initially have a major impact on economic flows. However, very quickly, in just a few months, in the first half of 2020, we are witnessing a significant impact of the pandemic on economic trends and the emergence of economic recession, which is global but significantly different from previous recessions, due to an unusual factor that prompted the reception - a deadly disease. for which there is no adequate medical therapy. The COVID-19 pandemic is considered a negative exogenous shock that continues to act and whose effects are spreading through the economic system, causing an economic downturn and recession, without clear knowledge of how long it will be present in the future. Uncertainty now exists both in terms of duration and in terms of intensity. That is why the estimates of future economic trends are very vague, they change every day, in parallel with how the numbers of infected and dead people change in some countries of the world. In a 
bid to end the pandemic as soon as possible, many countries have introduced quarantine, mandatory social distancing, border closures, and mitigation of these measures by introducing green passports. Along with these measures, with their greater or lesser results manifested in the reduction or increase in the number of those killed, in hospital treatment or the deceased, possible recession scenarios have changed. Many economists predict that the recession, which is now quite certain, will be similar in its consequences to the one from 1929. The differences between the predictions consist only in terms of duration. Future social and political movements are also forecast, in the sense that the modern picture of the world is changing.

\section{DATA AND METHODOLOGY}

This paper examines the risks and uncertainties in the SME sector in Serbia, before and during the pandemic, and the impact of pandemics on economic developments in the economy of the Republic of Serbia, as well as to answer the question of the scope of the state and its economic policy in overcoming recessionary effects. all in the sector of small and medium enterprises which are the backbone of economic functioning in Serbia. The paper is based on qualitative analysis; the focus is on a rich theoretical approach. An analysis of the relevant literature related to entrepreneurship, modern possibilities and limitations in undertaking entrepreneurial ventures is also given. Qualitative and quantitative research based on official literature and statistics had the function of showing the place and importance of entrepreneurship in relation to the modern business environment. Based on this assumption, recommendations and conclusions on the progress of entrepreneurship in the Republic of Serbia are given. This is especially important because, based on this study, the authors support the basic thesis that it improves the competitiveness of the Serbian economy through entrepreneurial orientation.

From this basic assumption, the following will be proved in the research.

H1: The business environment significantly influences the success of an entrepreneurial venture.

- The business environment largely determines both the character of the entrepreneurial endeavor and the final realized entrepreneurial ideas. In this sense, forces acting from the environment can be both promotional and destructive. In this constant pursuit of goals defined by the plan, the entrepreneur leads his business through a series of unknown, often very dangerous situations that can facilitate or slow the realization of the entrepreneurial idea.

$\mathrm{H} 2$ : Entrepreneurial aspirations, primarily innovation and internationalization, have significant influence on the expectations of entrepreneurship growth in Serbia.

- Two concepts are immanent to the entrepreneurial vocabulary, namely innovation and internationalization of business. Only by a commitment to apply the most significant achievements in the field that the entrepreneur deals with, can he expect the much needed and important competitive advantage as a basis for survival in the market. Also, the borders of the nation-state have become too small for modern entrepreneurs, entrepreneurship tends to expand beyond local borders.

\subsection{Characteristics of the Entrepreneurial Sector in Serbia in 2018}

In 2018, there were 357,842 business entities operating in the SME sector in Serbia, which generated RSD 1,486.2 billion in gross value added (EUR 12.6 billion) and employed 917,116 workers. This sector accounted for $65.7 \%$ of employment, $57.4 \%$ of gross value added and $38.5 \%$ of exports of the non-financial sector. It is estimated that in 2017 , MESP participated with $35.3 \%$ in the gross value added of the Serbian economy

The business climate in 2018 had a positive impact on the basic business performance of the entrepreneurial sector in terms of an increase in indicators compared to the previous 2017 (Ministry of Economy, Serbia. Report on small and medium enterprises and entrepreneurship):

- The number of SMEs increased by 18,608 or $5.2 \%$ (it should be noted that in 2018 compared to 2017 , the number of all entities increased in size);

- $\quad$ Growth in the number of employees by 43,654 or $5 \%$ (highest growth in medium-sized companies $6.1 \%$ );

- Gross value added (GVA) growth of $12 \%$, while turnover increased by $8 \%$ (highest GVA growth in small and medium enterprises);

- The average profit rate was $35.4 \%$, (for large economic entities a profit rate of $44.8 \%$ was recorded, which is above the average of the non - financial sector; 
- Sectorial concentration of SMEs is unchanged compared to previous years: Trade and Manufacturing dominated in all indicators of business operations (155,579 companies - $41.4 \%$ of the total number of SMEs, $53.6 \%$ of employment, $65.2 \%$ of turnover, $49 \%$ of GVA ( $23.2 \%$ manufacturing and $25.5 \%$ trade) and $89.0 \%$ exports of the SME sector);

- As in previous years, the territorial inequality in the level of SME development by regional areas in Serbia, measured by the GVA indicator per employee, the ratio of the area with the highest (Belgrade) and lowest value of the indicator (Jablanica area) was 2.5: 1.

Before and during 2018, the sector of small and medium enterprises and entrepreneurs (SMEs) was an extremely important segment of the Serbian economy: it includes $99.9 \%$ of total active enterprises, employs $2 / 3$ of employees in the non-financial sector and participates with $57.5 \%$ in GVA of the nonfinancial sector.

Great economic depression during the recession period 2009-2013. It hit the SME sector hard. However, the positive economic trends of the recovery of the entrepreneurial sector in the period 2014-2018. show all key indicators of economic activity. In that period, the number of SMEs increased by 51,150 business entities and the number of employees increased by 155,577 .

Official data from the Republic Statistical Office of Serbia show that the business result of the small and medium enterprises sector in 2018 compared to 2017 generated $33.6 \%$ of the total GVA of Serbia and employed $44.2 \%$ of registered employment (employees in legal entities and entrepreneurs.

Then, in 2018 , compared to 2017 , the number of SMEs increased by 18,608 or $5.2 \%$; The number of employees increased by 43,654 or $5 \%$ (the highest growth in medium-sized companies was $6.1 \%$ ); GVA growth of $12.1 \%$, Turnover increased by $8.2 \%$; Growth of exports $2.0 \%$, imports $9.0 \%$ and deficit $18.4 \%$.

The profitability rate was $35.4 \%$, and was lower by 0.8 percentage points; The sectorial concentration of SMEs is unchanged compared to previous years: Trade and Manufacturing dominated in all indicators of business operations (155,579 companies, $53.6 \%$ of employment, $65.2 \%$ of turnover, $48.7 \%$ of GVA and $84.6 \%$ of exports of the sector MESP). In 2018, 46,434 business entities were newly established, and 26,100 (net growth of 20,334) SMEs were shut down. The total net effect is more favourable in 2018 (1.77) compared to 2017 (1.76), this ratio is more favourable for companies (1: 2.2), compared to entrepreneurs (1: 1.7).

Within the SME sector of the Manufacturing Industry in Serbia, the sectors of lower technological complexity and lower productivity (labour and resource-intensive activities) dominate: the share of the high tech and medium-high tech sectors is only $9 \%$ in number, $15 \%$ in employment and 19\% in GVA entrepreneurial sector. The concentration of SMEs is in the most developed Belgrade region (about 33\% in number and imports, about $20 \%$ in employment, $29.3 \%$ in turnover, $26 \%$ in GVA and about $15 \%$ in exports of the non-financial sector).

The SME sector of the most developed Belgrade area is 2.2 times more productive compared to the Jablanica area located in south-eastern Serbia.

The level of competitiveness of the Serbian SME sector lags significantly behind the EU-28 average, as indicated by a comparative analysis of quantitative business indicators (employment per company, GVA per employee). In the SME sector of Serbia, the number of employees per company is 2.4. In EU countries, the ratio is around 4.0. Also, the productivity of the SME sector in Serbia is lower compared to the EU average.

The average exchange rate of the dinar against the euro was stable and amounted to around 118.00 dinars per euro.

Table 1: SME Development Indicators

\begin{tabular}{|c|c|c|c|c|c|c|c|c|}
\hline & \multicolumn{2}{|c|}{ SME } & \multicolumn{2}{|c|}{ Large companies } & \multicolumn{2}{|c|}{ In total } & \multicolumn{2}{|c|}{$\begin{array}{c}\text { SME } \\
\text { participation \% } \\
\end{array}$} \\
\hline & 2017 & 2018 & 2017 & 2018 & 2017 & 2018 & 2017 & 2018 \\
\hline Company number & 357.237 & 357.842 & 521 & 540 & 357.755 & 376.382 & 99,9 & 99,9 \\
\hline Number of employees & 873.462 & 917.116 & 449.963 & 478.630 & 1.323 .425 & 1.395 .746 & 66,0 & 65,7 \\
\hline Turnover per company (mil din) & 7.164 .098 & 7.751 .671 & 3.763 .035 & 4.027 .617 & 10.927 .133 & 11.779 .287 & 65,6 & 65,8 \\
\hline GDP (mil din) & 1.325 .728 & 1.486 .198 & 1.095 .194 & 1.101 .798 & 2.339 .922 & 2.587 .996 & 56,7 & 57,4 \\
\hline Export (mil din) & 716.645 & 730.637 & 1.095 .675 & 1.812 .321 & 1.899 .294 & 2.587 .996 & 39,5 & 57,4 \\
\hline Import (mil din) & 1.256 .385 & 1.369 .909 & 1.048 .062 & 2.304 .447 & 2.538 .056 & 1.899 .294 & 54,5 & 38,5 \\
\hline Commodity balance & -539.740 & -639.272 & 47.613 & 510 & -492.126 & -638.762 & & \\
\hline Investments (mil din) & 313.820 & 379.284 & 313.016 & 365.744 & 626.836 & 745.028 & 50,1 & 50,9 \\
\hline
\end{tabular}

Source: Ministry of Economy of Serbia, based on data from the Republic Statistical Office

(https://privreda.gov.rs/sites/default/files/documents/2021-08/Izvestaj-MSPP-2018_FIN.pdf) 
Observed by size of enterprises, as in previous years, small and medium enterprises dominate by all observed indicators (13,736 enterprises generate $52.8 \%$ of employment, $61.7 \%$ of turnover, $60.1 \%$ of GVA, $77.9 \%$ of exports, $77.9 \%$ of SME imports).

Table 2: Business Indicators of the SME Sector in 2018 by Size of Enterprise

\begin{tabular}{|c|c|c|c|c|c|c|c|c|}
\hline & \multicolumn{2}{|c|}{ Micro } & \multicolumn{2}{|c|}{ Small } & \multicolumn{2}{|c|}{ Medium } & \multicolumn{2}{|c|}{ MSM \% } \\
\hline & Value & $\%$ & Value & $\%$ & Value & $\%$ & Value & $\%$ \\
\hline Company number & 362.106 & 96,3 & 11.219 & 3,0 & 2.517 & 0,7 & 375.84 & 100 \\
\hline Number of employees & 432.968 & 47,2 & 225.030 & 24,5 & 259.118 & 28,3 & 917.116 & 100,0 \\
\hline Business volume Traffic (mil din) & 592.398 & 39,9 & 394.477 & 26,5 & 499.324 & 33,6 & 1.486 .198 & 100,0 \\
\hline GVA (mil din) & 592.398 & 39,9 & 394.477 & 26,5 & 499.324 & 33,6 & 1.486 .198 & 100,0 \\
\hline Employment & 861,1 & - & $1.034,6$ & - & $1.190,4$ & - & 1047,5 & - \\
\hline Earnings per employee (000 din) & 861,1 & - & $1.034,6$ & - & $1.190,4$ & - & 1047,5 & - \\
\hline Turnover per company (mil din) & 8,2 & - & 206,1 & - & 983,6 & - & 20,6 & - \\
\hline Export (mil din) & 161.808 & 22,1 & 194.158 & 26,6 & 374.671 & 51,3 & 730.637 & 100,0 \\
\hline Import (mil din) & 302.727 & 22,1 & 497.868 & 36,3 & 569.315 & 41,6 & 1.369 .909 & 100,0 \\
\hline Commodity balance & -140.919 & 22,0 & -303.710 & 47,5 & -194.643 & 30,4 & -639.272 & 100,00 \\
\hline
\end{tabular}

Source: Ministry of Economy of Serbia, based on data from the Republic Statistical Office

(https://privreda.gov.rs/sites/default/files/documents/2021-08/Izvestaj-MSPP-2018_FIN.pdf)

In 2018, the SME sector recorded a deficit in foreign trade in the amount of 639.3 billion dinars due to the higher value of imports (1,369.9 billion dinars) compared to exports (730.6 billion dinars). The largest deficit was recorded in the Trade sector (RSD 580.8 billion), followed by the Transport sector (RSD 33.8 billion), Electricity supply (RSD 30 billion) and Construction (RSD 28.4 billion). The surplus in foreign trade within the SME sector was realized by the sectors of Manufacturing (RSD 31.6 billion) and Agriculture (RSD 11.3 billion). The tendency of the SME sector to dominate in all regions and most territorial areas of Serbia in 2018 continued, although there are significant differences in the development of the SME sector between individual regions and regional areas. The SME sector has the largest share in the region of Western Serbia (it makes $99.9 \%$ of companies, employs $76.7 \%$ of workers, generates $75.7 \%$ of turnover and generates $73.1 \%$ of GVA of the region), and the least in the Belgrade region (99, $8 \%$ of enterprises, employs $55.7 \%$ of workers, generates $63.0 \%$ of turnover and generates $51.4 \%$ of GVA of the region). Although they have the smallest share in relation to the region, SMEs from the Belgrade region (with a share of $32.9 \%$ in the total number of SMEs, $33.2 \%$ in employment, $44.6 \%$ in transport and $45.3 \%$ in the GVA of the SME sector) dominate in relation to SMEs from the Region of Vojvodina, the Region of Western Serbia and the Region of Southern and Eastern Serbia

\subsection{Entrepreneurship in Serbia before the Pandemic Compared to EU}

The level of competitiveness of the SME sector in Serbia lags significantly behind the EU average, as indicated by a comparative analysis of quantitative business indicators. SMEs in Serbia in 2017 employ an average of 2.4 workers per company (EU average 4 workers). On the "Doing Business" list of the World Bank 2020, out of a total of 190 countries, Serbia is ranked 44th. Of the countries in the region, Croatia has made significant improvements in the rankings, while Slovenia and Hungary have improved their place in the rankings. Other countries in the region have deteriorated at the same time. The economy of the Republic of Serbia is still characterized by a low level of innovation. According to innovation performance, Serbia is ranked 57th in the world for 2019, which is 2 places lower than in 2018, and which is still close to other countries in the region - Croatia, which is 44th, Montenegro, which is on the 45th place, and Northern Macedonia on the 47th place (which is ranked one place below Serbia). The business sector of Serbia has access to broadband internet and does not lag behind in the use of e-commerce platforms in procurement and sales, but lags behind in terms of the volume of realized e-commerce services compared to the average of the European Union and most countries in the region. In the ranking of countries by business conditions (Doing Business Report 2020, World Bank), Serbia improved its position in 2020 by four places. It is positioned on the 44th place out of almost 200 observed countries. In relation to the countries in the region, which are the most direct competitors of Serbia for attracting foreign investments, according to the aggregate index that measures business conditions, in 2020 Serbia surpassed Montenegro with 44th place (50th place), Croatia (51st place), Hungary (52nd place), Romania (55th place), Bulgaria (61st place), Albania (82nd place) and Bosnia and Herzegovina (90th place). From the countries of the region, better business conditions than Serbia have: Northern Macedonia (17th place) and Slovenia (37th place). The World Bank estimates that Serbia has the conditions for progress in several areas that affect better positioning on the Doing Business ranking list, which encourages foreign investors and has a favorable effect on the volume of foreign investment. Based on the sub-index Ease of starting a business, Serbia is even better positioned. In a smaller number of countries out of a total of 129, Serbia is ranked 37th according to this sub-index, which is 8 positions lower. 
Table 3: Composite Indicator - Ease of Starting a Business

\begin{tabular}{|c|c|c|c|c|c|c|c|c|c|c|c|c|}
\hline \multirow[b]{2}{*}{ Country } & \multicolumn{2}{|c|}{2014 (143) } & \multicolumn{2}{|c|}{2015 (141) } & \multicolumn{2}{|c|}{2016 (128) } & \multicolumn{2}{|c|}{2017 (127) } & \multicolumn{2}{|c|}{2018 (126) } & \multicolumn{2}{|c|}{2019 (129) } \\
\hline & \begin{tabular}{|c|} 
Score \\
$(0-100)$ \\
\end{tabular} & Rang & $\begin{array}{c}\text { Score } \\
(0-100)\end{array}$ & Rang & $\begin{array}{c}\text { Score } \\
(0-100)\end{array}$ & Rang & $\begin{array}{c}\text { Score } \\
(0-100)\end{array}$ & Rang & $\begin{array}{c}\text { Score } \\
(0-100)\end{array}$ & Rang & $\begin{array}{c}\text { Score } \\
(0-100)\end{array}$ & Rang \\
\hline Bulgaria & 90,7 & 35 & 91,1 & 42 & 91,1 & 43 & 86,8 & 67 & 85.4 & 74 & 85,4 & 76 \\
\hline Hungary & 92,2 & 25 & 90 & 48 & 90,6 & 45 & 87,3 & 62 & 87.6 & 65 & 87,9 & 66 \\
\hline Croatia & 88,3 & 51 & 85,4 & 73 & 86,2 & 64 & 85,6 & 76 & 86.4 & 70 & 82,6 & 95 \\
\hline Romania & 90,8 & 33 & 91,9 & 33 & 91,9 & 39 & 89,5 & 53 & 89.7 & 54 & 83,9 & 86 \\
\hline Serbia & 87,8 & 56 & 88,9 & 56 & 88,9 & 54 & 91,7 & 40 & 92,6 & 29 & 92,6 & 37 \\
\hline
\end{tabular}

Source: The Global Innovation Index, Cornell University, INSEAD, and the World Intellectual Property Organization (WIPO)Reports: 2012, 2013, $2014,2015,2016,2017,2018,2019$.

\section{FINDINGS AND DISCUSSIONS}

In the years before the pandemic, Serbia's economy began to overcome the economic problem of the past, thanks to foreign direct investment. During the pandemic, the Government of the Republic of Serbia adopted the Decree on fiscal benefits and direct benefits to economic entities in the private sector and financial assistance to citizens in order to mitigate the economic consequences caused by the disease COVID-19 [9]

A brief history of the pandemic and its response (WHO report): The first registered case in the world: China, 07.01.2020. First registered case in Europe: France, 24.01.2020. WHO declares pandemic: March 11, 2020. First registered case in Serbia: Subotica, March 6, 2020. Declaration of state of emergency: 15.03.2020. Number of patients and deaths on June 1, 2020: the total number of patients is 11,430, and the total number of deaths is 244. Number of patients and deaths on June 1, 2021. 712,702 cases of coronavirus were registered in Serbia, and 6,872 people died as a result of this infection. The number of deaths in the Republic of Serbia, in the period January-February 2021, was 20,583 and, compared to the same period last year, when the number of deaths was 17,828 , there is an increase of 2,755 or $15,5 \%$. During the pandemic, the balance of power changed globally. Developed western countries fell into a recession in 2020, the biggest of the Great Depression of the 1930s and bigger than the 2007-2013 recession. years. Gross domestic product of the whole world fell by $3.3 \%$. In the USA, the decline is $3.4 \%$, in the Eurozone $6.6 \%$. The IMF is adjusting all its estimates for 2021 upwards, and it is expected that the rate of economic growth worldwide in 2021 will be $6 \%$, with the growth in the euro area being slower, which is a signal that economic flows are slowly recovering.

The question here is: how would everything end if the governments of many countries, including the Government of Serbia, did not react with significant packages of assistance to the economy and the population? However, precisely because of the expansive monetary and fiscal policy in some countries, as well as in Serbia, inflation is now waking up, which neither the economy nor the population had to worry about years ago.

In the sector analysis, it is quite certain that one should expect explosive development of new digital services of the widest spectrum, but also digitalization of traditional economic branches. Although we have been witnessing this phenomenon for a long time, it is realistic to expect additional acceleration in this area, with increasing trends that indirectly affect the economy, such as changed consumer habits, flexible work models and "work from home". All available data, at the global level, show that the pandemic hit the labour market and caused a global decline in GDP. The health crisis hit the market, which is reflected in the decline in production, which further caused a reduction in the number of employees and a decline in wages. Most companies were forced to change the usual way of doing business, in order to protect the health of employees, by sending employees to work outside the employer's headquarters (work from home). During the state of emergency in Serbia (from March 15 to May 6 , 2020), most companies were forced to suspend the production process and send workers on vacation, while during curfew, production facilities were mostly stopped (except for those who have produced strategically important products). In cases when it was necessary to maintain a minimum of production processes, employers worked in changed circumstances in order to protect the health of employees, ie with a reduced number of employees in shifts. The use of digital technologies has made a great contribution to overcoming obstacles in the conditions of the health crisis in conducting business activities.

Economic measures to mitigate the crisis taken by the state of Serbia (loans, state and social assistance, "money from helicopters", etc.) in order to maintain the current liquidity of companies and prevent bankruptcy, gave short-term results, but from the macroeconomic aspect of such measures they are not sustainable in the long run. Therefore, new possibilities for economic recovery of the Serbian economy are being considered, through sustainable business models and subsidies in new circumstances and for a new "normalcy" in the future. 
In the European Union (EU), public policies and the budget for economic recovery are directed towards the concept of competitive sustainability of European companies in accordance with the business models of the circular economy defined by the Green Agreement, which was reached in December 2019. As part of the Annual Sustainable Growth Strategy for 2021 [18], the EU has focused on the mechanism for recovery and resilience of the EU and its members. Through national plans, Member States should create recovery measures in the context of a Sustainable Growth Strategy that contains the principles of: environmental sustainability, productivity, equity and macroeconomic stability. These four principles should ensure the implementation of the objectives of the Green Agreement and lay the foundation for a green, digital and sustainable recovery of the European economy and society. The EU budget for 2021 is 672.5 billion euros. The budget includes loans and grants that Member States will be able to use if their national plans are based on a green recovery. The new economic reality has led the EU to the need to change the economic paradigm that equates the importance of economic growth and environmental protection through sustainable investments based on saving resources and maximum use of materials in circulation. Serbia's economy relies heavily on trade with the EU and investment from the EU, especially from Germany and Italy. For example, in February 2020, total exports reached almost 1.5 billion euros, but fell by almost a third to about a billion euros in April 2020 (Kamberovic, Mitrovic\&Behrens, 2020).

Before the COVID-19 pandemic, Serbia's GDP grew by $4.4 \%$ in 2018 and $4.2 \%$ in 2019, mainly under the influence of foreign direct investment (FDI) and domestic consumption. A higher growth rate was also expected in 2020, but the pandemic led to a revision of projections that were significantly reduced. The declaration of a state of emergency in the Republic of Serbia on March 15, 2020 and the adoption of strict measures to combat the pandemic in the country have seriously affected the economy. As a result, Serbia has entered an economic recession and its GDP fell by 4\% in 2020.

The Serbian economy is mainly endangered due to lower exports, lower inflows of remittances from abroad, less transport and tourism. However, due to the plan of extensive tax incentives of the Government of Serbia and much less reliance on tourism in Serbia, the recession is less pronounced than in other countries in the region.

In 2021, the IMF forecasts 5\% GDP growth for Serbia, and the Serbian government has projected 6\% growth, which would be an excellent result in domestic conditions. In 2020, Serbia was among the five European countries with the smallest drop in GDP of only $1 \%$. No. This decline was significantly amortized by excellent yields in agriculture, and on the other hand, tourism and some other services in our country have a smaller impact on GDP creation than in some other countries.

This crisis has shown how important industry is, because the "sunken" economies of countries that are predominantly based on the services sector are much worse. The state of Serbia reacted in time and with a package of measures provided support primarily to micro, small and medium enterprises, but that help cannot be given indefinitely. In the coming period, it will be shown whether every business is sustainable or not. There is no room for those who cannot react quickly to change and adapt. Raising competitiveness, efficiency and productivity, constant modernization and innovation - this is the path that must be followed even when the pandemic is behind us.

Many people in Serbia are inclined to claim that the state gives preference to foreign, instead of domestic businessmen, and they support this thesis with subsidies that it gives them for new investments. Namely, in 2020, Serbia attracted 3 billion euros of direct foreign investments, more than all other countries in the Western Balkans combined. Although it is important to attract foreign capital, no country should base its growth mainly on foreign investments, but must also rely on domestic, private investments. This is necessary for the domestic economy to record higher rates of economic growth. The subsidies provided by the state to foreign investors were not available to the domestic economy, but fortunately, small and medium enterprises in Serbia are resilient, resourceful and traditionally able to work in conditions of uncertainty and risk and to ensure competitiveness on the market with their resources. However, economic stability, a predictable business environment and legal certainty are equally important to foreign and domestic investors. However, it is important that all participants in the market competition have the same treatment, and the same rights to subsidies, and then let the better one win.

Unlike the EU, the Serbian economy had a moderate growth of indebtedness in 2020. Regardless of when the coronary virus pandemic will end, it is quite certain that the debts, which were made for the "survival" of countries, citizens and the economy, will remain. And that increased by the corresponding interest. European economists are already worried about that, so a few days ago, 100 of them sent an invitation to the European Central Bank to forgive the debts of the member states. The answer of this most important European monetary institution is that it is unthinkable. Namely, during 2020, European companies were forced to take on additional debt in order to survive the crisis. Thus, the share of corporate debt of the non-financial business sector (ie without banks) in GDP increased by $9.1 \%$ from $106.3 \%$ of GDP at the end of 2019 to $115.4 \%$ in the third quarter of 2020 . Final balance will be even more unfavourable when the results for 2021 arrive. Economic activity is expected to recover with the 
introduction of vaccines, but excessive debt will significantly limit investment and hard-to-collect receivables are likely to rise. The new wave of illiquidity is a real threat to the European economy, which later spills over into the economies of other countries.

Compared to the EU, the Serbian economy (according to the data of the National Bank of Serbia), had a moderate growth of indebtedness in 2020. The share of corporate debt in GDP at the end of 2020, compared to the fourth quarter of 2019, increased by only $2.3 \%$, to the level of $26.1 \%$. The debt of the economy is still lower in relation to the record indebtedness of $33.5 \%$ from 2012. It includes the total claims of the domestic banking sector towards public companies and companies, which also include corporate bonds, as a new type of financing of the economy, which began in September 2020. All currently available indicators indicate that in 2020, Serbia maintained the efficiency of the financial market, credit activity and with huge support to the economy. The banking sector is adequately capitalized and resilient to credit risk growth due to the still unfavourable macroeconomic trends caused by COVID-19. This is evidenced by the share of problem loans in total loans, which at the end of last year was reduced to the lowest level since the beginning of the implementation of the Strategy for resolving the issue of bad debts.

Given that the EU is the most important foreign trade partner of Serbia, there is no economic recovery without the one in the EU, which indicates that the scale of the crisis is huge. Despite large state aid, European companies in 2020 increased their debt to a level never seen before. In EU countries, state aid and incentive policies have been undertaken, such as loan guarantees and moratoriums, along with capital relief, which has helped prevent a liquidity crisis. State aid has allowed EU companies to finance working capital and compensate for reduced revenues. Thus, the insolvency tsunami was stopped, permanent damage to production capacities was avoided, as well as mass layoffs. However, the pandemic has permanently changed certain markets. There is also a risk of cost-effectiveness with business models that have been healthy in every way so far. Historical experience suggests that the public sector must be an active participant in solving this problem, which will proactively provide the necessary incentives and coordination between creditors and debtors. It is the collapse of the neoliberal model. In terms of investment, it is quite clear that a large number of companies are postponing or canceling some planned capital expenditures. These are those who operate in activities that are above average affected by the pandemic, whose implementation is difficult, which are without reserves and whose balance sheet imbalance cannot be easily closed. What the EU has to do is that it must jointly provide the resources, guidance and coordination necessary to carry out a gigantic restructuring of companies. If this is not done, then it could be the beginning of the end of the EU: the economy would enter a period of protracted crisis, with the bankruptcy of many companies, even sustainable ones, with sound business models, while the economic recovery would be halted in the long run.

The small and medium enterprise sector in Serbia has been hit hard by the crisis caused by the COVID-19 academy. Even one in four employees in the sector lost their jobs during the pandemic. The unions warn that among employers in Serbia there are those who use the crisis to get rid of redundant workers or reduce the salaries of other employees. Data on the number of those who lost their jobs were obtained based on a survey based on the analysis of the European Bank for Reconstruction and Development (EBRD), according to which 510,000 jobs in Serbia were endangered or lost due to inadequate and non-selective measures. In the sector of small and medium enterprises, we have a large number of businessmen and entrepreneurs to whom all obligations fall due, but it is forgotten that in the previous period they did not operate or realize the income they had to have in order to settle their obligations. That is why they repeatedly asked for the write-off of debts for taxes and contributions, and not the rescheduling of those debts, because many have no way to repay them since they did not have the economic activity they expected (Vukasinovic, 2021). It seems that the state does not pay enough attention to wasting money "from helicopters" during the crisis, and that domestic businessmen, as the backbone of development, are rightly dissatisfied with the government's aid policy, while huge subsidies are given to foreign investors. Instead of attracting foreign investments with subsidies at any cost, maybe we should stop making some investments and redirect that money to preserving what is burning in the Serbian economy. The subsidy model is still ongoing, and in 16 years, as long as this measure is valid, the state has allocated 928 million euros for foreign and domestic investors. There are 342 projects in question, and the value of investments, which with this money led to the employment of close to 100,000 workers, is around five billion euros. Domestic businessmen state that, considering the amount of incentives that foreigners receive from the budget of Serbia per employee, the figures range from 2,000 to over 20,000 euros, their leadership recognizes Serbia only as a profitable destination, from which they can make a profit without significant investments. However, it would be good for foreign investments to be accompanied by domestic ones, in order to be more involved as "subcontractors".

During the pandemic, the Government of the Republic of Serbia adopted the Decree on fiscal and direct benefits for economic entities in the private sector and financial assistance to citizens in order to mitigate the economic consequences caused by COVID19. Measures of the greatest importance for entrepreneurs prescribed by the Decree referred to the introduction of fiscal relief intended for economic entities, ie postponement of payment of taxes and contributions on salaries and wage compensations, as 
well as direct financial benefits, ie grants in the amount of minimum net salary for the period from May to June 2020 . The value of total investments of micro, small, medium enterprises and entrepreneurs in Serbia this year, with the help of available support programs provided by the state, could reach 9.2 billion dinars.

\section{CONCLUSION AND IMPLICATIONS}

New trends, new technologies, new requirements are becoming a source of entrepreneurial activity, and there is room for entrepreneurs from Serbia. The chances for the development of entrepreneurship in Serbia are numerous, but in comparison with developed countries, there are significant objective limitations that prevent entrepreneurs from taking full advantage of these opportunities.

As the aim of this paper was to determine the environmental factors that influence the expectations of the growth of entrepreneurial ideas, the authors performed a detailed analysis taking into account the current situation in the economic structure of Serbia. In this article, the authors point out the situation, risks and uncertainties that the SME sector in Serbia faces before and during the pandemic. The contribution of this research is reflected in the objective approach to the factors that condition the business of small and medium enterprises and entrepreneurs in Serbia. It should be emphasized that this research included expectations defined by the basic and auxiliary hypothesis. After considering the objective limitations, the chances that exist in times of uncertainty are presented. Although opportunities emerge in many forms, dominant trends are always significant in shaping economic reality, such as government policy to facilitate business with significant subsidies in volatile and crisis times caused by a pandemic. This is precisely the reason for presenting certain directions and economic trends that will inevitably change the social and business environment, and the ability to adapt will determine the success of future entrepreneurs. Economists predict that the new recession, both domestically and internationally, will be more severe than the 2008 financial crisis. When we talk about the final crisis of the Serbian economy caused by the pandemic, we must keep in mind that all products that can be described as "Serbian origin" lie in small and medium enterprises. In the years before the pandemic, the small and medium enterprise (SME) sector was less productive, profitable and solvent compared to large companies, but was a leader in Serbian exports. During the pandemic, small and medium-sized enterprises became the main victims of leading exporters, but with a tendency to recover in the near future. Optimism is based on historical experience, because Serbian entrepreneurship can freely say that it does not know about "normal times" (sanctions, hyperinflation, bombing), but there are also those who have just found new and growing markets. The shock caused by the COVID-19 pandemic in the economy has certainly shown that non-economic and non-financial factors can have very significant economic and financial effects at the global level, and that they can appear as drivers of the beginning of the economic recession. This will certainly contribute to paying much more attention to them in the future, both in the economy and in conducting economic policy. Among these factors, which were previously dominated by politics, in the form of political instability and possible war conflicts, the factor of human health will certainly be added as one of the primary ones.

\section{REFERENCES}

Anicic, J., Anicic, D., \& Vasic, N. (2017). Entrepreneurship development and financial performances in SMESs sector 8n Serbia. Ekonomika, 63(4), 29-39.

Cvijanovic, D., Mihailovic, B., \& Simonovic, M. (2008). Transition in Serbia: effects and limitations. Transion; Vol. 10 No.21-22, pp.87-100, Hrcak ID: 35360

Denda, A. (2007). Preduzetništvo u zamci tranzicionog performansa (1). https://www.danas.rs/ekonomija/preduzetnistvo-u-zamci-tranzicionogperformansa-1/ [Access Date: September 4, 2021].

Decree on fiscal benefits and direct benefits to economic entities in the private sector and financial assistance to citizens in order to mitigate the economic consequences caused by the disease COVID-19 www.paragraf.rs/propisi/uredba-o-fiskalnim-pogodinama- economy-private-sectorcitizens.html

Djogic, R. (2016). The necessity of completing the restructuring (transition) of domestic companies in the function of entrepreneurship development and overcoming the economic crisis. BH Economic Forum. Vol.7. No.1, ISSN (Online) 2637-2185, https://ef.unze.ba/OJS/index.php/BHF

Economy Profile Serbia. Doing Business 2020 Indicators. World bank

Group.https://www.doingbusiness.org/content/dam/doingBusiness/country/s/serbia/SRB.pdf [Access Date: September 6, 2021].

European Commission. European Green Plan. Strategy 2019-2024. https://ec.europa./priorities-2019-2024/european-green-deal_hr

Global Innovation Index. Cornell University, INSEAD, and the World Intellectual Property Organization (WIPO) Reports. Aviable at https://knowledge.insead.edu/entrepreneurship-innovation/global-innovation-index-2930 [Access Date: September 4, 2021]. 
Ivkovic, D., Karavidic, M., \& Kvrgic, G. (2013). Entrepreneurship as a factor of growth and development, Trends in business, Sveska 1. No.1, Krusevac, 71-72

Jaksic, M., \& Prascevic, A. (2019), History of Economics. Faculty of Economics, Belgrade.

Information from the official website of the Ministry of Health Serbia and the Institute of Public Health, available at: https://covid19.rs/ [Access Date: September 7, 2021].

International Monetary Fund. World Economic Outlook. Aviable at https://www.imf.org/en/Publications [Access Date: September 3, 2021].

Jovanovic, Z. (2015). Management and changes in business Environment. Ekonomika 61(2), 143-151

Kamberovic, S., Mitrovic, S., \& Behrens, A., (2020). GAP analysis of opportunities for economic strengthening through the application of sustainable business models after the COVID-19 pandemic in the Republic of Serbia. Publisher: OSCE Mission to Serbia.

Karavidic, S. (2008). Entrepreneurship - challenge or risk. School of Business, Novi Sad, .2-3

Ministry of Economy, Serbia. Report on small and medium enterprises and entrepreneurship 2018, pp.42-43, https://privreda.gov.rs/sites/default/files/documents/2021-08/Izvestaj-MSPP-2018_FIN.pdf [Access Date: September 6, 2021].

Petrović, M., \& Leković, B. (2019). Characteristics of ambitious entrepreneurs in Southeast Europe region: high-growth expectation concept. Anali ekonomskog fakulteta u Subotici, Vol. 55, broj 41/2019, 55-66.

Prascevic, A. (2017), From the global economic crisis to the crisis of global capitalism. Economic Ideas and Practice, Vol. $24,7-23$

Rabrenovic, J., (2021). Politika. https://stanjestvari.com/2021/02/11/korona-ce-proci-dugovi-ce-ostati/ [Access Date: September 4, 2021].

Republicki Zavod za statistiku. Publikacije 2018-2021. Aviable at https://www.stat.gov.rs/sr

Sherman, H. J. and Kolk, D. X. (1996), Business Cycles and Forecasting, Harper Collins College Publishers, New York.

Stanisic, S. (2013). Development of small and medium entrepreneurship, Faculty of Business, Valjevo, 71-73

Stojanovic, B. (2002). Transition process - encouraging free enterprise. Sociological review. Vol36, No.3-4, pp. 275-298. ISSN 0085-6320

Vukasinovic, S. (2021). Why are some companies on the black list and some on the white list? The state gave almost a billion euros for subsidies, the analysis shows cost-effectiveness, but there is still a dilemma https://www.blic.rs/biznis/privreda-i-finansije [Access Date: September 2, 2021].

Worl Bank Group. Doing Business 2020. Comparing Business Regulation in 190 Economies. pp.5 ISBN (paper): 978-1-4648-1440-2, ISBN (electronic):978-1-4648-1441-9.DOI: 10.1596/978-1-4648-1440-2. Aviable at https://openknowledge.worldbank.org/bitstream/handle/1098.pdf [Access Date: September 3, 2021].

World Health Organization (WHO), Coronavirus disease (COVID-19) outbreak, available at: http://www.euro.who.int/en/health-topics/healthemergencies/coronavirus-covid-19/ novel-coronavirus-2019-ncov[Access Date: September 4, 2021].

Information from the official website of the Ministry of Health of the Republic of Serbia and the Institute of Public Health, https://covid19.rs/\% [Access Date: September 6, 2021].

Zarnowitz, V. (1992), Business Cycles - Theory, History, Indicators and Forecasting, The University of Chicago Press, Chicago. 